\title{
Effect of Dietary Nano Zinc Oxide Supplementation on Haematological Parameters, Serum Biochemical Parameters and Hepato-Renal Bio-Markers in Crossbred Calves
}

\author{
T. S. V. Anil ${ }^{1 *}$, Ch. Venkata Seshaiah ${ }^{2}$, P. Ashalatha ${ }^{3}$ and K. Sudhakar ${ }^{4}$ \\ ${ }^{1}$ Rajamahendravaram Division, East Godavari District, Andhra Pradesh, India \\ ${ }^{2}$ Livestock Farm Complex, NTR College of Veterinary Science, Sri Venkateswara Veterinary \\ University, Gannavaram, Andhra Pradesh, India \\ ${ }^{3}$ Department of Livestock Production Management, NTR College of Veterinary Science, \\ Sri Venkateswara Veterinary University, Gannavaram, Andhra Pradesh, India \\ ${ }^{4}$ Department of Animal Genetics and Breeding, NTR College of Veterinary Science, \\ Sri Venkateswara Veterinary University, Gannavaram, Andhra Pradesh, India \\ *Corresponding author
}

\section{A B S T R A C T}

\begin{tabular}{|l|}
\hline Ke y w o r d s \\
Crossbred calves, \\
Biochemical, \\
Haematological \\
parameters, \\
Supplementation
\end{tabular}

\section{Introduction}

Proper mineral nutrition is the key to successful dairying. Mineral deficiencies lead

to disease resulting in economic loss to the
To investigate the changes in the haematological, serum biochemical parameters and hepato-renal biomarkers upon dietary supplementation of nano zinc oxide (nZnO) and its effect on growth performance in calves, 24 weaned (6 months age) crossbred calves were randomly distributed to four dietary plans (Control, Treatment1, Treatment2 and Treatment3). The Control(C) group was fed exclusively with basal diet; T1 was supplemented with 25ppm ZnSo4, T2 and T3 with 5ppm and 10ppm nZnO respectively, along with the basal diet. Zinc content in basal was $26.24 \mathrm{ppm}$. The haematological parameters and few parameters viz., serum calcium, SGOT, blood urea nitrogen and creatinine varied within the normal range upon $\mathrm{nZnO}$ supplementation. However, the serum zinc, total protein, serum albumin and serum globulin were significantly $(\mathrm{P}<0.01)$ higher in $\mathrm{nZnO}$ supplemented groups. There was a significant $(\mathrm{P}<0.05)$ difference in the blood glucose levels between $\mathrm{C}$ and $\mathrm{T} 2$ on 45th day. And, the serum phosphorus level was significantly $(\mathrm{P}<0.05)$ higher in $\mathrm{T} 2$ compared to $\mathrm{T} 1$ and $\mathrm{T} 3$. To conclude, $\mathrm{nZnO}$ has significant effect on few serum biochemical parameters which supported the growth performance of calves positively with a significant $(\mathrm{P}<0.01)$ improvement in the body weight gain and average daily gain in $\mathrm{nZnO}$ supplemented groups. farmer and Zinc is no exception. Zinc is a trace mineral which caters many of the operating metabolic functions in the body, aids in animal growth, health, reproduction and production. It conjugates with DNA- 
binding protein to regulate gene expression participating in the nucleic acid (Hambidge et $a l ., 1986)$ and protein synthesis (Hidiroglou, 1980) to affect the growth rate of animals (Chesters 1997 and MacDonald 2000). It is a nutrient involved in functioning of a variety of enzymes related to glucose, protein and lipid metabolism, in hormone production and secretion. Zinc also influences immune system function (Shinde et al., 2006).

Many of the signalling pathways are zinc dependent (Beattie and Kwun, 2004; Cousins et al., 2006). The normal serum $\mathrm{Zn}$ concentration is generally between 0.7 and $1.3 \mathrm{~g} / \mathrm{ml}$ and the dietary requirements of $\mathrm{Zn}$ for calves is about $33 \mathrm{mg} / \mathrm{kg}$ (NRC, 2001). $\mathrm{Zn}$ is reported to be deficient in several parts of India (Alloway, 2004) in general and Andhra Pradesh in particular (Nagalakshmi et al., 2009) which reflectes in the Zn deficiency in fodder. Adding to this, the soy bean meal (contains phytates) which is a common component of concentrate mixture and unintended excess levels of Calcium in general and few other elements like Fe and $\mathrm{Cu}$ in the diet of animals depress the zinc absorption and bioavailability. To avoid $\mathrm{Zn}$ deficiency, the common practice is to add conventional $\mathrm{Zn}$ supplements, over and above the recommended level.

But, the conventional zinc is poorly soluble and has lower bioavailability and requires regular supplementation to maintain optimal $\mathrm{Zn}$ levels in blood. Zinc lack storage reserves in the body and high doses of zinc causes toxicity with degenerative changes in liver, kidney and pancreas (Allen et al., 1983). In the present study nano zinc has been used which has the advantage of higher bioavailability at a lower rate of inclusion (Patil et al., 2009). The haemopoetic system actively responds to the exogenous substances and to the changes of concentration and exposure duration of exogenous substances
(Dimitrova et al., 2010). Few studies have reported that higher $\mathrm{Zn}$ intake is associated with severe cytopenia (Irving et al., 2003). While some reported that, the dietary $\mathrm{Zn}$ supplementation has no influence on few or all the haematological parameters in different species of livestock and poultry (Ramulu et al., 2015; Elamin et al., 2013; Milani et al., 2017). However, very scanty information is available on haemoto-biochemical parameters upon supplementation of $\mathrm{nZnO}$ especially in crossbred calves. So this work was taken up to investigate the changes in haematological and biochemical parameters upon $\mathrm{nZnO}$ supplementation in crossbred calves.

\section{Materials and Methods}

24 crossbred calves of 6 months age which were randomly distributed in four groups (Control, Treatment1, Treatment2 and Treatment3) of six calves in a completely randomized block design. Calves were kept in well ventilated house with concrete flooring having provision of individual feeding and watering and also provided a 15-day adaptation period where the calves were fed with basal diet. The concentrate mixture was prepared with all the minerals except Zinc. The zinc content in the basal diet was found to be $26.24 \mathrm{ppm}$ which was tested using inductively coupled plasma atomic emission spectroscopy (ICP-OES).

Deworming and deticking was done before the start of the experiment. The calves were assigned to different dietary treatments viz., Control(C) group where calves were fed with basal diet only, T1, T2 and T3 were supplemented with $25 \mathrm{ppm} \mathrm{ZnSo} 4$, 5ppm and $10 \mathrm{ppm}$ of $\mathrm{nZnO}$ respectively, along with the basal diet. Two blood samples were collected aseptically at fortnight intervals via a single jugular venepuncture from each calf, one sample was collected into EDTA vaccutainer for haematological analysis and the other 
sample into an anti-coagulant free centrifuge tube to obtain serum. The whole blood collected into EDTA vaccutainer was kept for analysis of haematological constituents $(\mathrm{Hb}$, RBC, WBC, Platelets and MCV) using automatic haematology analyser. Serum samples were obtained after centrifuging whole blood at $2000 \mathrm{x} \mathrm{g}$ for $10 \mathrm{~min} ; 4^{\circ} \mathrm{C}$ in refrigerated centrifuge and serum was collected into eppendorf tubes and stored.

Serum stored in eppendorf tubes was analysed for serum biochemical parameters and few basic hepato-renal biomarkers (Serum Ca, $\mathrm{P}$, $\mathrm{Zn}$, Albumin, Globulin, Total Protein, Glucose, SGOT, BUN and Creatinine) using commercially available kits of Erba Mannheim and Genx Proton Bologicals (zinc kit). The concentrations of the parameters in serum and data analysis of results were performed using spectrophotometer and ANOVA, Post-hoc tests in SPSS version (15.01) (SPSS, 2006) respectively.

\section{Results and Discussion}

\section{Haematological parameters}

The results on the effect of dietary supplementation of $\mathrm{nZnO}$ on $\mathrm{Hb}$ concentration, RBC, WBC, Platelet count and $\mathrm{MCV}$ in crossbred calves are represented in the Table 1 . The result revealed that there was no statistically significant difference with regard to all the haematological parameters among the groups as the parameters varied within the physiological normal range.

The results are in agreement with the findings of Ramulu et al., (2015) in buffalo calves and Milani et al., (2017) in weanling pigs observed no significant difference in all the haematological parameters upon supplementation of conventional zinc and nZnO respectively. Similarly, Elamin et al., (2013) found no effect of supplemental zinc on $\mathrm{Hb}$ concentration, $\mathrm{RBC}$ and WBC count in goat Kids. Also, Ismail and El-Araby (2017) in rabbits found no observable variation in the $\mathrm{Hb}$ concentration and RBC count. In contrary, Sobhanirad et al., (2014) reported a statistically significant difference in all the haematological parameters of lambs among the groups upon supplementation of $\mathrm{Zn}$. Also, Ismail and El-Araby (2017) found a highly significant increase in total leukocytic count in $\mathrm{ZnO}$ NPs supplemented rabbits groups.

$\mathrm{Zn}$ at higher concentrations tends to inhibit copper and iron absorption (Salama et al., 2003) which are required for RBC and WBC proliferation and maturation. Here in the present study, the haematological parameters were in normal range which could be due to the level of inclusion of $\mathrm{Zn}$ of the study which might not have interfered with the $\mathrm{Cu}$ and $\mathrm{Fe}$ so as to affect the haemogram.

\section{Serum glucose level}

The results of effect of dietary supplementation of $\mathrm{nZnO}$ on serum glucose level of crossbred calves are represented in the Table 2. The statistical analysis revealed that there was no significant difference in serum glucose level among the groups except on 45th day $(\mathrm{P}<0.05)$ where the mean serum glucose level was higher in control group compared to groups supplemented with $\mathrm{ZnO}$. Similar to the results of our study, the serum glucose levels in poultry birds did not differ significantly between control and zinc supplemented groups (Sahoo et al., 2014; Fathi., 2016 and Idowu et al., 2011). In contrary, Sethy et al., (2016) and Elamin et al., (2013) reported that the serum glucose concentration in goats increased significantly $(\mathrm{P}<0.05)$ between the groups supplemented with inorganic and organic zinc in diet. Similar findings were made by Mishra et al., (2014) in chicks supplemented with nano zinc. 


\section{Serum mineral parameters}

The results of effect of dietary supplementation of $\mathrm{nZnO}$ on different serum minerals are presented in the Table 3 suggesting that the calcium remained unchanged, phosphorus was significantly $(\mathrm{P}<0.05)$ higher in nano zinc supplemented group on 30th day of experiment and serum zinc level was significantly higher $(\mathrm{P}<0.01)$ in the groups supplemented with nano zinc oxide@10ppm.

The results of our study are in accordance with the findings of Zaboli et al., (2013) in Markhoz goat kids and Sahoo et al., (2014) in broiler chicks who did not observe any significant difference in serum concentration of $\mathrm{Ca}$ and $\mathrm{P}$ among the groups upon supplementation of nano zinc. Similarly, Sahoo et al., (2014) and Raya et al., (2016) found that nanoparticles increased serum zinc concentration significantly in broilers and rats respectively. Garg et al., (2008) also reported that the supplementation of zinc had no effect on serum inorganic P levels. Further, Dresler et al., (2016) in cattle calves and Ramulu et al., (2015) in buffalo calves observed a significant increase in serum zinc concentration when nano zinc is supplemented and $\mathrm{Li}$ et al., (2016) in weanling pigs observed a significant increase in serum zinc concentration when nano zinc is supplemented.

In contrary, Al-Daraji and Amen (2011) reported a significantly $(\mathrm{P}<0.05)$ higher level of serum calcium and phosphorus on increasing zinc levels in the diets of broilers. But, Daghash and Mousa (1999) and Thilsing and Jorgensen (2001) noticed a significant drop in serum calcium level in buffaloes and cows respectively when supplemented with conventional zinc in their diets. Abedini et al., (2017) reported that plasma zinc concentration was not significantly affected by the supplementation of layer diet with different sources of zinc. Similarly, Zaboli et al., (2013) and Najafzadeh et al., (2013) also reported that there were no significant differences in serum concentrations of $\mathrm{Zn}$ between the groups supplemented with different forms to zinc in goat kids and lambs respectively. However, Phiri et al., (2009) reported that supplementation of zinc oxide to goats decreased the phosphorus concentration in the blood.

Many studies indicated that there exists an antagonistic effect between zinc and calcium. However, in the present study the dietary supplemental zinc might have been not so high as to affect the levels of calcium in the serum. From the results of the present study, it is very clear that, the level of inclusion of zinc in the study has no prominent effect on serum phosphorus levels in crossbred calves. The raise in serum zinc levels of the groups supplemented with $\mathrm{nZnO}$ in the present study was obvious and is attributed to the higher bioavailability of $\mathrm{nZnO}$ when compared to the conventional zinc source (Sahoo et al., 2014).

\section{Serum protein parameters}

\section{Serum albumin}

The results on the effect of dietary supplementation of $\mathrm{nZnO}$ on serum protein components level in crossbred calves are represented in the Table 4. Statistical analysis revealed that the mean albumin concentration in serum of all calves varied within the normal range with serum albumin being significantly $(\mathrm{P}<0.01)$ lower in $\mathrm{T} 1$ compared to $\mathrm{C}, \mathrm{T} 2$ andT3 on 15th, 30th, 75th days of experiment. Similar results were documented by Ramulu et al., (2015) and Sahoo et al., (2014) who observed that the serum albumin was comparable among experimental groups supplemented with different sources of zinc in calves and broiler chicks respectively. 
In contrary, a significant increase in serum albumin concentration in crossbred was reported in calves fed a diet containing different sources of Zinc by Mandal (2004) and Dresler et al., (2016). Similar findings were reported by Nobijari et al., (2012) in young Holstein bulls. In contrary, the results of Ismail and El-Araby (2017) showed that there is a highly significant decrease in albumin levels in ZnO NPs group of rabbits.

\section{Serum globulin}

The results on the effect of dietary supplementation of $\mathrm{nZnO}$ on serum protein components level in crossbred calves are represented in the Table 4. Statistical analysis revealed that the serum globulin levels were significantly $(P<0.01)$ higher in group supplemented with $\mathrm{nZnO} \quad @ \quad 10 \quad$ ppm compared to other groups.

The increased globulin concentrations in serum of crossbred calves supplemented with $\mathrm{nZnO}$ might be attributed to the functional role of zinc in protein synthesis and this improved globulin level implies to better immune response as serum globulins playing a role in immune response (immunoglobulins or antibodies) and provide an early line of defence.

In accordance to the present study, the reports of Ramulu et al., (2015) in buffalo calves and (Gaafar et al., 2011) in lactating Friesian cows witnessed a significant increase in serum globulin concentration among the experimental groups supplemented with zinc.

In contrary with our results, Ismail and ElAraby (2017) showed that there is a highly significant decrease in globulin levels of Rabbits fed with $\mathrm{ZnO}$ NPs. On the other hand, Sahoo et al., (2014) observed no significant variation in serum globulin levels ofbroiler chicks treated with different sources of zinc.

\section{Total protein}

The results on the effect of dietary supplementation of $\mathrm{nZnO}$ on serum protein components level in crossbred calves are represented in the Table 4. Statistical analysis revealed that there was a significantly $(\mathrm{P}<0.01)$ higher total protein levels in the serum of groups supplemented with nZnO @ $10 \mathrm{ppm}$ compared to the other groups and control. The improved total protein concentration in serum of crossbred calves supplemented with $\mathrm{nZnO}$ might be attributed to the functional role of zinc in protein synthesis as suggested by Ibs and Rink (2003).

The results of the present study are in agreement with the reports of Nobijari et al., (2012) in young Holstein bulls and Dresler et al., (2016) in calves wherein the zinc supplementation increased the total protein levels significantly $(P<0.05)$. In contrary, Ismail and El-Araby (2017) observed that there is a highly significant decrease in serum total protein levels in rabbits supplemented with $\mathrm{ZnO}$ NPs in the diet. On the other hand, the findings of Sahoo et al., (2014) and Fathi (2016) in broiler chicks and Ramulu et al., (2015) in buffalo calves revealed that there was no significant variation in serum total protein levels among the groups treated with different sources of zinc.

\section{Albumin to globulin (A/G) ratio}

The results on the effect of dietary supplementation of $\mathrm{nZnO}$ on serum protein components level in crossbred calves are represented in the Table 4. Statistical analysis revealed that the $A / G$ ratio varied within the normal range in all the groups with $\mathrm{A} / \mathrm{G}$ being significantly $(\mathrm{P}<0.01)$ low in the $\mathrm{nZnO}$ supplemented groups. Similarly, Mishra et al., (2014) found relatively lower A/G ratio in the groups supplemented with $\mathrm{nZnO}$ when 
compared to the control group. In contrary, Bahakaim et al., (2014) found that the organic source of zinc significantly improved A/G ratio in layers compared to the inorganic source. However, the results of Sahoo et al., (2014) in broiler chicks and Sethy et al., (2016) in goats revealed that albumin to globulin ratio in the groups treated with different sources of zinc was comparable.

\section{Hepatic and renal health biomarkers}

The results on the effect of dietary supplementation of $\mathrm{nZnO}$ on hepatic and renal health biomarkers in crossbred calves are represented in the Table 5. The results revealed that the levels of SGOT, BUN and Creatinine in serum of $\mathrm{CB}$ calves varied within the normal range. Any abnormal increase in SGOT (Aranda-Michel and Sherman., 1998), BUN and Creatinine concentration could imply hepatic and renal dysfunction. The results of the present study imply that the rate of inclusion of $\mathrm{nZnO}$ has no toxic effects on hepatic and renal function.

\section{Serum glutamic oxaloacetic transaminase (SGOT)}

The results of the present study show that there was no significant difference in SGOT levels between the $\mathrm{CB}$ calves supplemented with $\mathrm{nZnO}$ and without $\mathrm{nZnO}$, showing that $\mathrm{nZnO}$ has no significant influence on the SGOT levels in CB calves. SGOT is a relatively specific indicator of acute liver cell damage and hepatic dysfunction. The results are in accordance with Najafzadeh et al., (2013) and Milani et al., (2017) who found that supplementation of $\mathrm{Zn}$ NPs had no influence on SGOT levels in lambs and pigs respectively.

Fathi (2016) and Sahoo et al., (2014) reported that there was no significant variation in serum SGOT levels of broiler chicks treated with nano zinc oxide and other sources of zinc. Wang et al., (2016) also reported that long term exposure of mice to doses of nanoZnOs did not affect the serum activities of SGOT. In contrary to the results of the current study, Ismail and El-Araby (2017) reported that there was a highly significant increase in SGOT activity in ZnO NPs supplemented rabbits.

\section{Blood urea nitrogen (BUN)}

The results of the current study show that there was no significant difference in the BUN levels between the groups. Our results are in agreement with the findings of Najafzadeh et al., (2013) who found that the zinc oxide nanoparticles administration in lambs had no effect on the levels of BUN in serum. Similar results were obtained by Sahoo et al., (2014) in broiler chicks. In contrary, Nobijari et al., (2012) and Dresler et al., (2016) observed that the zinc supplementation in calves increased the blood urea nitrogen levels. However, Dresler et al., (2016) documented a drastic drop in the serum urea levels towards the end of the experiment.

\section{Serum creatinine}

Statistical analysis revealed that there was no significant difference among the groups with respect to creatinine. The results of the present study are in accordance with the findings of Atakisi et al., (2009) who reported that there was no significant difference in the creatinine levels among the groups upon supplementation of zinc in Japanese quails. In contrary, Najafzadeh et al., (2013) observed that the serum creatinine concentration in serum was significantly increased after oral administration of nano zinc particles in lambs. Ismail and El-Araby (2017) stated that there was a highly significant increase in serum creatinine when rabbits are supplemented with zinc oxide NPs in their diets. 
Table.1 Effect of nZnO supplementation on haematological parameters in crossbred calves

\begin{tabular}{|c|c|c|c|c|c|}
\hline Parameter & Day & Control & Treatment 1 & Treatment 2 & Treatment 3 \\
\hline \multirow[t]{2}{*}{ Hb (g/dl) } & 0 Day & $9.4 \pm 0.30$ & $7.91 \pm 0.16$ & $9.66 \pm 0.80$ & $9.26 \pm 0.80$ \\
\hline & $90^{\text {th }}$ Day & $10.07 \pm 0.26$ & $9.2 \pm 0.06$ & $9.7 \pm 0.21$ & $10.12 \pm 0.37$ \\
\hline \multirow[t]{2}{*}{ RBC $\left(\times 10^{6} / \mathrm{uL}\right)$} & 0 Day & $9.36 \pm 0.44$ & $9.3 \pm 0.40$ & $9.61 \pm 0.77$ & $9.21 \pm 0.83$ \\
\hline & $90^{\text {th }}$ Day & $9.54 \pm 0.46$ & $9.58 \pm 0.22$ & $9.50 \pm 0.37$ & $9.74 \pm 0.27$ \\
\hline \multirow[t]{2}{*}{ WBC $\left(\times 10^{3} / \mathrm{uL}\right)$} & 0 Day & $10.93 \pm 0.71$ & $11.18 \pm 0.38$ & $11.42 \pm 0.38$ & $11.25 \pm 1.20$ \\
\hline & $90^{\text {th }}$ Day & $11.32 \pm 0.48$ & $11.27 \pm 1.1$ & $11.58 \pm 0.43$ & $11.33 \pm 0.81$ \\
\hline \multirow{2}{*}{$\begin{array}{l}\text { Platelets (x } \mathbf{1 0}^{3} \\
\text { /uL) }\end{array}$} & 0 Day & $533.5 \pm 27.8$ & $501.20 \pm 21.9$ & $514.70 \pm 31.57$ & $507.20 \pm 18.54$ \\
\hline & $90^{\text {th }}$ Day & $557.3 \pm 16.15$ & $563.8 \pm 21.54$ & $578.30 \pm 12.77$ & $577.5 \pm 17.34$ \\
\hline \multirow[t]{2}{*}{$\operatorname{MCV}(f L)$} & 0 Day & $34.02 \pm 0.65$ & $32.67 \pm 1.20$ & $31.82 \pm 1.50$ & $33.32 \pm 1.06$ \\
\hline & $90^{\text {th }}$ Day & $36.33 \pm 0.67$ & $32.65 \pm 0.78$ & $33.63 \pm 1.50$ & $34.02 \pm 1.11$ \\
\hline
\end{tabular}

Means with different superscripts in a row differ significantly $(* \mathrm{P}<0.05),(* * \mathrm{P}<0.01)$

Table.2 Effect of Nano zinc oxide supplementation on serum glucose in CB calves

\begin{tabular}{|l|l|l|l|l|}
\hline Glucose(mg/dL) & Control & Treatment 1 & Treatment 2 & Treatment 3 \\
\hline 0 Day & $72.69 \pm 2.89$ & $83.70 \pm 1.28$ & $76.28 \pm 3.04$ & $89.00 \pm 8.67$ \\
\hline $\mathbf{4 5}^{\text {th }}$ Day* & $83.77 \pm 1.55^{\mathrm{a}}$ & $78.68 \pm 4.10^{\mathrm{a}}$ & $60.59 \pm 9.05^{\mathrm{b}}$ & $82.69 \pm 9.53^{\mathrm{a}}$ \\
\hline $\mathbf{9 0}^{\text {th }}$ Day & $81.10 \pm 3.99$ & $76.59 \pm 3.79$ & $81.24 \pm 2.33$ & $71.56 \pm 8.76$ \\
\hline
\end{tabular}

Means with different superscripts in a row differ significantly $(* \mathrm{P}<0.05),(* * \mathrm{P}<0.01)$

Table.3 Effect of nZnO supplementation on some serum minerals in crossbred calves

\begin{tabular}{|c|c|c|c|c|c|}
\hline Parameter & Day & Control & Treatment 1 & Treatment 2 & Treatment 3 \\
\hline \multirow[t]{2}{*}{ Calcium(mg/dL) } & 0 Day & $10.81 \pm 0.37$ & $10.47 \pm 0.33$ & $10.12 \pm 0.11$ & $9.83 \pm 0.15$ \\
\hline & $90^{\text {th }}$ Day & $10.44 \pm 0.46$ & $10.46 \pm 0.39$ & $9.80 \pm 0.10$ & $10.07 \pm 0.15$ \\
\hline \multirow[t]{2}{*}{ Phosphorus(mg/dL) } & 0 Day & $7.50 \pm 0.41$ & $7.23 \pm 0.20$ & $8.22 \pm 0.41$ & $7.25 \pm 0.35$ \\
\hline & $90^{\text {th }}$ Day & $8.02 \pm 0.19$ & $7.75 \pm 0.07$ & $7.94 \pm 0.08$ & $7.82 \pm 0.06$ \\
\hline \multirow[t]{2}{*}{ Zinc(ug/dL) } & o Day & $60.28 \pm 2.55$ & $61.43 \pm 1.92$ & $63.57 \pm 2.19$ & $67.35 \pm 1.08$ \\
\hline & $\begin{array}{l}\text { 90 } \\
\text { Day** }\end{array}$ & $86.41 \pm 0.93^{d}$ & $91.27 \pm 0.97^{\mathrm{c}}$ & $94.83 \pm 0.59^{b}$ & $98.34 \pm 0.72^{\mathrm{a}}$ \\
\hline
\end{tabular}

Means with different superscripts in a row differ significantly $(* \mathrm{P}<0.05),(* * \mathrm{P}<0.01)$ 
Table.4 Effect of $\mathrm{nZnO}$ supplementation on serum protein components in crossbred calves

\begin{tabular}{|c|c|c|c|c|c|}
\hline Parameter & Day & Control & Treatment 1 & Treatment 2 & Treatment 3 \\
\hline \multirow[t]{2}{*}{ Albumin (g/dL) } & $0^{\text {th }}$ Day & $1.88 \pm 0.08$ & $1.76 \pm 0.13$ & $1.87 \pm 0.14$ & $1.46 \pm 0.12$ \\
\hline & $90^{\text {th }}$ Day & $2.58 \pm 0.18$ & $2.74 \pm 0.14$ & $2.48 \pm 0.14$ & $2.63 \pm 0.21$ \\
\hline \multirow[t]{2}{*}{ Globulin (g/dL) } & 0 Day & $2.59 \pm 0.10$ & $3.02 \pm 0.06$ & $2.60 \pm 0.18$ & $3.235 \pm 0.21$ \\
\hline & 90 ${ }^{\text {th }}$ Day* & $3.48 \pm 0.24^{b}$ & $4.33 \pm 0.15^{\mathrm{a}}$ & $3.92 \pm 0.15^{\mathrm{ab}}$ & $3.84 \pm 0.21^{\mathrm{ab}}$ \\
\hline \multirow{2}{*}{$\begin{array}{l}\text { Total Protein } \\
\text { (g/dL) }\end{array}$} & 0 Day & $4.47 \pm 0.11$ & $4.79 \pm 0.13$ & $4.48 \pm 0.09$ & $4.70 \pm 0.18$ \\
\hline & $90^{\text {th }}$ Day* & $6.06 \pm 0.29^{b}$ & $7.07 \pm 0.18^{\mathrm{ab}}$ & $6.40 \pm 0.21^{\mathrm{ab}}$ & $6.47 \pm 0.17^{\mathrm{a}}$ \\
\hline \multirow[t]{2}{*}{ A/G Ratio } & 0 Day & $0.73 \pm 0.05$ & $0.58 \pm 0.04$ & $0.75 \pm 0.10$ & $0.47 \pm 0.65$ \\
\hline & $90^{\text {th }}$ Day & $0.61 \pm 0.08$ & $0.63 \pm 0.04$ & $0.63 \pm 0.04$ & $0.70 \pm 0.82$ \\
\hline
\end{tabular}

Means with different superscripts in a row differ significantly $(* \mathrm{P}<0.05),(* * \mathrm{P}<0.01)$

Table.5 Effect of nZnO supplementation on hepato-renal biomarkers in crossbred calves

\begin{tabular}{|l|l|l|l|l|l|}
\hline Parameter & Day & Control & Treatment 1 & Treatment 2 & Treatment 3 \\
\hline SGOT (IU/L) & 0 Day & $53.00 \pm 2.47$ & $52.73 \pm 1.98$ & $55.82 \pm 2.3$ & $54.21 \pm 1.96$ \\
\cline { 2 - 6 } & $\mathbf{9 0}^{\text {th }}$ Day & $57.83 \pm 1.84$ & $51.99 \pm 1.73$ & $56.23 \pm 2.60$ & $55.63 \pm 1.89$ \\
\hline BUN (mg/dL) & 0 Day & $13.46 \pm 0.52$ & $13.80 \pm 0.65$ & $13.86 \pm 0.67$ & $14.15 \pm 041$ \\
\hline & $\mathbf{9 0}^{\text {th }}$ Day & $14.23 \pm 0.76$ & $13.71 \pm 0.79$ & $14.41 \pm 0.76$ & $13.71 \pm 0.79$ \\
\hline $\begin{array}{l}\text { Creatinine } \\
\text { (mg/dL) }\end{array}$ & 0 Day $^{\text {90 }}$ & $1.10 \pm 0.18$ & $0.90 \pm 0.17$ & $0.92 \pm 0.25$ & $1.03 \pm 0.22$ \\
\hline
\end{tabular}

Means with different superscripts in a row differ significantly $(* \mathrm{P}<0.05),(* * \mathrm{P}<0.01)$

The inclusion of $\mathrm{nZnO}$ has significant effect on some serum biochemical parameters which support the growth performance of calves positively.

\section{Acknowledgments}

Authors are thankful to Sri Venkateswara Veterinary University, Tirupati for having providing the facilities to carry out this study.

\section{References}

Abedini, M., Shariatmadari, F., Torshizi, M. K. and Ahmadi, H. (2017). Effects of a dietary supplementation with zinc oxide nanoparticles, compared to zinc oxide and zinc methionine, on performance, egg quality, and zinc status of laying hens. Livestock Science, 203: 30-36.

Al-Daraji, H. J., and Amen, M. H. (2011). Effect of dietary zinc on certain blood traits of broiler breeder chickens. Int $J$ Poult Sci, 10(10): 807-813.

Allen, J. G., Masters, H. G., Peet, R. L., Mullins, K. R., Lewis, R. D., Skirrow, S. Z. and Fry, J. (1983). Zinc toxicity in ruminants. Journal of Comparative Pathology, 93(3): 363-377.

Alloway, B. J. (2004). Zinc in soils and crop nutrition. International Zinc Association, Brussels, 130.

animal nutrition 2:499.

Aranda-Michel, J. and Sherman, K. E. (1998). Tests of the liver: use and misuse. The Gastroenterologist, 6(1): 34-43. 
Atakisi, O., Atakisi, E. and Kart, A. (2009). Effects of Dietary Zinc and 1-Arginine Supplementation on Total Antioxidants Capacity, Lipid Peroxidation, Nitric Oxide, Egg Weight, and Blood Biochemical Values in Japanese Quails. Biological trace element research, 132(1-3): 136-143.

Bahakaim, A. S. A., Magied, H. A. A., Osman, S. M. H., Omar, A. S., AbdelMalak, N. Y. and Ramadan, N. A. (2014). Effect of using different levels and sources of zinc in layer's diets on egg zinc enrichment. Egyptian Poultry Science Journal, 34: 39-56.

Beattie, J. H. and Kwun, I. S. (2004). Is zinc deficiency a risk factor for atherosclerosis?. British Journal of Nutrition, 91(2): 177-181.

Chesters, J. K. (1997). Zinc. In: Hand Book of Nutritionally Essential Mineral Elements (Ed. B. L. O'Dell and R. A. Sunde) Marcel Dekker Inc. New York. pp. 185-230.

Cousins, R. J., Liuzzi, J. P. and Lichten, L. A. (2006). Mammalian zinc transport, trafficking, and signals. Journal of Biological Chemistry, 281(34): 2408524089.

Daghash, H. A. and Mousa, S. M. (1999). Zinc sulfate supplementation to ruminant rations and its effects on digestibility in lamb; growth, rectal temperature and some blood constituents in buffalo calves under heat stress. Assiut Vet. Med. J, 40: 128-146.

Dimitrova, A., Russeva, A., Atanasova, M., and Strashimirov, D. (2010). Effects of zinc supplementation on some hematological parameters of spontaneously hypertensive rats. Trakia Journal of Sciences, 8(2): 61-65.

Dresler, S., Illek, J. and Zeman, L. (2016). Effects of organic zinc supplementation in weaned calves. Acta Veterinaria Brno, 85(1): 49-54.
Elamin, K. M., Dafalla, N. A., Abdel Atti, K. A. and Tameem Eldar, A. A. (2013). Effects of zinc supplementation on growth performance and some blood parameters of goat kids in Sudan. International Journal of Pure and Applied Biological Research and Sciences, 1(1):1-8.

Fathi, M. (2016). Effects of zinc oxide nanoparticles supplementation on mortality due to ascites and performance growth in broiler chickens. Iranian Journal of Applied Animal Science, 6(2): 389-394.

Fathi, M., Haydari, M., and Tanha, T. (2016). Effects of zinc oxide nanoparticles on antioxidant status, serum enzymes activities, biochemical parameters and performance in broiler chickens. Journal of Livestock Science and Technologies, 4(2):7-13.

Gaafar, H. M. A., Bassiouni, M. I., Ali, M. F. E., Shitta, A. A. and Shamas, A. S. E. (2011). Effect of zinc methionine supplementation on productive performance of lactating Friesian cows. J. Anim. Sci. Biotech, 2(2): 94-101.

Garg, A. K., Mudgal, V., and Dass, R. S. (2008). Effect of organic zinc supplementation on growth, nutrient utilization and mineral profile in lambs. Animal feed science and technology, 144(1-2): 82-96.

Hambidge, K.M., Casey, C.E. and Krebs, N.F. (1986). Zinc: Trace elements in human and animal nutrition, 2(1-137) 5th ed. Academic Press, Orlando, Fla.

Hidiroglou, M. (1980). Trace elements in the fetal and neonate ruminant: a review. The Canadian Veterinary Journal, 21(12): 328.

Ibs, K. H. and Rink, L. (2003). Zinc-altered immune function. The Journal of nutrition, 133(5): 1452S-1456S.

Idowu, O. M. O., Ajuwon, R. O., Oso, A. O. and Akinloye, O. A. (2011). Effects of 
zinc supplementation on laying performance, serum chemistry and $\mathrm{Zn}$ residue in tibia bone, liver, excreta and egg shell of laying hens. International Journal of Poultry Science, 10(3): 225230.

Irving, J. A., Mattman, A., Lockitch, G., Farrell, K. and Wadsworth, L. D. (2003). Element of caution: a case of reversible cytopenias associated with excessive zinc supplementation. Canadian Medical Association Journal, 169(2), 129-131.

Ismail.,H. T. H. and El-Araby., I .E. (2017). Effect of dietary zinc oxide nanoparticles supplementation on biochemical, hematological and genotoxicity parameters in rabbits. International Journal of Current Advanced Research, 6: 2108-2115.

Li, M. Z., Huang, J. T., Tsai, Y. H., Mao, S. Y., Fu, C. M. and Lien, T. F. (2016). Nanosize of zinc oxide and the effects on zinc digestibility, growth performances, immune response and serum parameters of weanling piglets. Animal Science Journal, 87(11): 13791385.

MacDonald, R. S. (2000). The role of zinc in growth and cell proliferation. The Journal of nutrition, 130(5): 1500S$1508 \mathrm{~S}$

Mandal, G. P. (2004). Effect of Zinc Suppplementation on Growth Metabolic Profile and Immunity in Crossbred Calves (Doctoral dissertation, IVRI).

Milani, N. C., Sbardella, M., Ikeda, N. Y., Arno, A., Mascarenhas, B. C. and Miyada, V. S. (2017). Dietary zinc oxide nanoparticles as growth promoter for weanling pigs. Animal Feed Science and Technology, 227, 13-23.

Mishra, A., Swain, R. K., Mishra, S. K., Panda, N. and Sethy, K. (2014). Growth performance and serum biochemical parameters as affected by nano zinc supplementation in layer chicks. Indian J. Anim. Nutr, 31(4): 384-388.

Nagalakshmi, D., Ramulu, S. P. and Rani, M. U. (2012). Effect of graded levels of zinc supplementation on growth performance and oxidative defense mechanism in rats. IOSR J. Pharmacy, 2: 36-41.

Nagalakshmi, D., Reddy, M.R. and Prasad, M.R. (2009). Mineral status of dairy animals in high altitude and tribal zone of Andhra Pradesh. In: NAAS Proceedings of ANA world conference, 14th $-17^{\text {th }}$ February, 2009, New Delhi.

Najafzadeh, H., Ghoreishi, S. M., Mohammadian, B., Rahimi, E., Afzalzadeh, $\quad$ M. R., Kazemivarnamkhasti, M. and Ganjealidarani, H. (2013). Serum biochemical and histopathological changes in liver and kidney in lambs after zinc oxide nanoparticles administration. Veterinary World, 6(8): 534-537.

National Research Council. (2001). Nutrient requirements of dairy cattle. National Academies Press.

Nobijari, F. H., Amanlou, H. and DehghanBanadaky, M. (2012). Effects of zinc supplementation on growth performance, blood metabolites and lameness in young Holstein bulls. Journal of applied animal research, 40(3): 222-228.

Patil, S. S., Kore, K. B. and Kumar, P. (2009). Nanotechnology and its applications in Veterinary and Animal Science. Veterinary World, 2(12): 475-477.

Phiri, E. C. J. H., Viva, M. M., Chibunda, R. T. and Mellau, L. S. B. (2009). Effect of Zinc Supplementation on Plasma Mineral Concentration in Grazing Goats in Sub-Humid Climate of Tanzania. Tanzania Veterinary Journal, 26(2): 9296.

Ramulu, S. P., Nagalakshmi, D. and Kumar, 
M. K. (2015). Effect of zinc supplementation on haematology and serum biochemical constituents in Murrah buffalo calves. Indian J. Anim. Res, 49(4): 482-486.

Raya, S. D. H. A., Hassan, M. I., Farroh, K. Y., Hashim, S. A. and Salaheldin, T. A. (2016). Zinc oxide nanoparticles fortified biscuits as a nutritional supplement for zinc deficient rats. $J$. Nanomed. Res, 4(00081): 10-15406.

Sahoo, A., Swain, R. K. and Mishra, S. K. (2014). Effect of inorganic, organic and nano zinc supplemented diets on bioavailability and immunity status of broilers. Int. J. Adv. Res, 2(11): 828837.

Salama, A. A., Caja, G., Albanell, E., Such, X., Casals, R. and Plaixats, J. (2003). Effects of dietary supplements of zincmethionine on milk production, udder health and zinc metabolism in dairy goats. Journal of Dairy Research, 70(1): 9-17.

Sethy, K., Behera, K., Mishra, S.K., Gupta, S.K., Sahoo, N., Parhi, S.S., Mahapatra, M.R. and Khadanga, S. (2016) Effect of organic zinc supplementation on growth, metabolic profile and antioxidant status of Ganjam sheep. Cellulose, 10: 42-50.

Shinde, P., Dass, R. S., Garg, A. K.,
Chaturvedi, V. K. and Kumar, R. (2006). Effect of zinc supplementation from different sources on growth, nutrient digestibility, blood metabolic profile, and immune response of male Guinea pigs. Biological trace element research, 112(3): 247-262.

Sobhanirad, S., Mashhadi, M. H. and Kashani, R. B. (2014). Effects of source and level of zinc on haematological and biochemical parameters in Baluchi lambs. Research Opinions in Animal and Veterinary Sciences, 4(7): 389-393.

Thilsing-Hansen, T. and Jørgensen, R. J. (2001). Serum calcium response following oral zinc oxide administrations in dairy cows. Acta Veterinaria Scandinavica, 42(2): 271.

Wang, C., Lu, J., Zhou, L., Li, J., Xu, J., Li, W. and Wang, T. (2016). Effects of long-Term exposure to Zinc oxide nanoparticles on development, Zinc metabolism and biodistribution of minerals ( $\mathrm{Zn}, \mathrm{Fe}, \mathrm{Cu}, \mathrm{Mn}$ ) in mice. PloS one, 11(10): 00164434.

Zaboli, K., Aliarabi, H., Bahari, A. A. and Abbas, A. K. R. (2013). Role of dietary nano-zinc oxide on growth performance and blood levels of mineral: A study on in Iranian Angora (Markhoz) goat kids. Journal of Pharmaceutical and Health Sciences, 2(1):19-26.

\section{How to cite this article:}

Anil, T. S. V., Ch. Venkata Seshaiah, P. Ashalatha and Sudhakar, K. 2020. Effect of Dietary Nano Zinc Oxide Supplementation on Haematological Parameters, Serum Biochemical Parameters and Hepato-Renal Bio-Markers in Crossbred Calves. Int.J.Curr.Microbiol.App.Sci. 9(04): 2034-2044. doi: https://doi.org/10.20546/ijcmas.2020.904.243 